\title{
Article
}

\section{Softening of Processed Plant Virus Infected Cucumis sativus L. Fruits}

\author{
Anne-Katrin Kersten ${ }^{1,2, *}$, Sabrina Scharf ${ }^{3} \mathbb{D}$, Martina Bandte ${ }^{2} \mathbb{D}$, Peer Martin ${ }^{4}$, Peter Meurer ${ }^{3}$, Peter Lentzsch ${ }^{1}$ \\ and Carmen Büttner ${ }^{2}$
}

1 Leibniz Centre for Agricultural Landscape Research (ZALF), Research Area 1 "Landscape Functioning", 15374 Müncheberg, Germany; lentzsch@zalf.de

2 Division Phytomedicine, Albrecht Daniel Thaer-Institute, Faculty of Life Science, Humboldt-Universität zu Berlin, 14195 Berlin, Germany; martina.bandte@agrar.hu-berlin.de (M.B.); carmen.buettner@agrar.hu-berlin.de (C.B.)

3 Department of Agriculture and Food Sciences, Neubrandenburg University of Applied Sciences, 17033 Neubrandenburg, Germany; scharf@hs-nb.de (S.S.); meurer@hs-nb.de (P.M.)

4 Molecular Parasitology, Institute of Biology, Faculty of Life Science, Humboldt-Universität zu Berlin, 10115 Berlin, Germany; peer.martin@alumni.hu-berlin.de

* Correspondence: anne-katrin.kersten@zalf.de; Tel.: +49-33432-82-452

check for updates

Citation: Kersten, A.-K.; Scharf, S.; Bandte, M.; Martin, P.; Meurer, P.; Lentzsch, P.; Büttner, C. Softening of Processed Plant Virus Infected Cucumis satious L. Fruits. Agronomy 2021, 11, 1451. https://doi.org/ 10.3390/agronomy11081451

Academic Editor: Salvatore Davino

Received: 9 June 2021

Accepted: 19 July 2021

Published: 21 July 2021

Publisher's Note: MDPI stays neutral with regard to jurisdictional claims in published maps and institutional affiliations.

Copyright: (c) 2021 by the authors. Licensee MDPI, Basel, Switzerland. This article is an open access article distributed under the terms and conditions of the Creative Commons Attribution (CC BY) license (https:/ / creativecommons.org/licenses/by/ $4.0 /)$.
Abstract: Texture softening of pickled cucumbers does not meet consumers' quality expectations and leads to economic losses. The factor(s) triggering this phenomenon is still unknown. We investigated the importance of plant viruses such as Cucumber green mottle mosaic tobamovirus (CGMMV) and Zucchini yellow mosaic potyvirus (ZYMV) in the context of softening of pickles. Cucumber plants (Cucumis sativus) were infected by mechanical inoculation, grown under greenhouse conditions and tested positive for the viral infection by ELISA. The severity of virus infection was reflected in yield and symptom expression. Histological and morphological alterations were observed. All fruits were pasteurized, separately stored in jars and subjected to texture measurements after four, six and 12 months. CGMMV-infections were asymptomatic or caused mild symptoms on leaves and fruit, and texture quality was comparable to control. At the same time, fruits of ZYMV-infected plants showed severe symptoms like deformations and discoloration, as well as a reduction in firmness and crunchiness after pasteurization. In addition, histological alterations were detected in such fruits, possibly causing textural changes. We conclude that plant viruses could have a considerable influence on the firmness and crunchiness of pickled cucumbers after pasteurization. It is possible that the severity of symptom expression has an influence on texture properties.

Keywords: ZYMV; CGMMV; texture quality; fruit firmness; canned fruits; pickles; cell structure alterations; cucumber

\section{Introduction}

Cucumbers (Cucumis sativus L.) rank among one of the most widely cultivated cucurbits worldwide, with China representing the largest producer of cucumbers and gherkins $[1,2]$. C. sativus belongs to the family Cucurbitaceae, commonly known as cucurbits and gourds, with members like melon (Cucumis melo L.), squash and pumpkin (Cucurbita spp.). Cucumbers are consumed fresh, cooked or preserved. The processing of these fruits targets preservation with minimal texture damage. Crunchiness and firmness are major textural determinants and dominant drivers of pickled cucumbers in regard to consumer sensory preferences [3-5]. Economic losses due to texture damage (softness) of stored pickles can only be overcome with improvements in their durability by identifying the cause of the softening [6]. Brands such as Spreewald gherkins (PGI) from Eastern Germany must maintain product quality to remain globally competitive.

Structural components of the fruit like pectin and cellulose, in addition to turgor and cell wall elasticity, are decisive for the texture quality. [7-9]. These and other compounds 
can be influenced by many pre- and postharvest abiotic and biotic factors such as strong light intensity, water stress, fungi and pests $[10,11]$. Above all, process parameters during manufacturing have been speculated to be possible contributors to the softening of pickles and have been extensively investigated. Various studies on the salt content [12], $\mathrm{pH}$ value [13], type of vinegar used [14] and stabilizing additives [15] which improved processing and storage, were unsuccessful in inhibiting softening of pickled cucumbers. Even the optimization of heat treatment during pasteurization [16], as well as storage temperature [17], could not deflate the factor(s) causing softening. Microbiological and enzymatic investigations appeared more promising $[18,19]$. However, studies showed less heat tolerance of those enzymes which are needed for surviving pasteurization [20].

The current study was the first to investigate the influence of plant viruses on the texture of pickled cucumbers. Plant viruses have been shown to manipulate various plant physiological processes and enzymes, thus affecting the health, appearance and yield of agricultural crops [21,22].

Cucumber green mottle mosaic tobamovirus (CGMMV) [23] and Zucchini yellow mosaic potyvirus (ZYMV) [24] belong to economically relevant pathogens of cucurbits and threaten cultivation worldwide due to extensive global trade and their simple transmissibility by aphids and mechanical means [25]. The single-stranded positive-sense RNA viruses differ greatly in their phenotypic symptom expression in cucumber plants and fruits. ZYMV generally causes severe symptoms such as blistering, stunting, mosaic and filamentous leaf phenotype, as well as deformed fruits. This often results in significant losses of nonmarketable fruits due to their atypical appearance. Infections with ZYMV in cucumber fields occur worldwide and have already occurred in the Spreewald (a large cucumbergrowing region in eastern Germany) during this project. CGMMV causes mild symptoms like mottling on young cucumber leaves and fruits but can also lead to the collapse of the plant $[26,27]$.

Based on our investigations, the importance of these plant viruses in relation to pickle softening is discussed. Infected cucumbers were harvested, pasteurized and stored in jars [28]. Texture measurements of infected cucumbers have provided information on the influence of the viruses on the fruit texture.

\section{Materials and Methods}

\subsection{Virus Inoculation and Cultivation of Plants}

C. sativus cultivars (F1 hybrids) 'Platina' (Nunhems Germany GmbH, Marbach, Germany), 'Profi' (Graines Voltz, Colmar, France), 'Liszt' and 'Dirigent' (Rijk Zwaan Welver $\mathrm{GmbH}$, Welver, Germany) were grown under greenhouse conditions over a 16:8 h light:dark photoperiod at an average of $26.8^{\circ} \mathrm{C}$ and $49.7 \%$ relative humidity. These cultivars were chosen because they are cultivated commercially. Universal fertilizer WUXAL ${ }^{\circledR}$ (Wilhelm Haug GmbH \& Co. KG, Düsseldorf, Germany) was applied weekly starting with the 7th week after sowing (100 mL of 1:1000 Fertilizer-water-solution). Two plants of the same cultivar were cultivated in a $40 \mathrm{~L}$ soil bag (Substrat 1, Klasmann-Deilmann GmbH, Geeste, Germany). Four cucumber plants per cultivar were artificially infected by mechanical inoculation of cotyledons with freeze-dried infected leaf material of ZYMV (strain PV-0466, German Collection of Microorganisms and Cell Cultures (DSMZ), Braunschweig, Germany) or CGMMV (strain PV-0375, DSMZ, Braunschweig, Germany) according to the supplier's instructions. Two plants per cultivar were similarly treated but using virus-free plant material (mock inoculation, control) (Figure 1). 


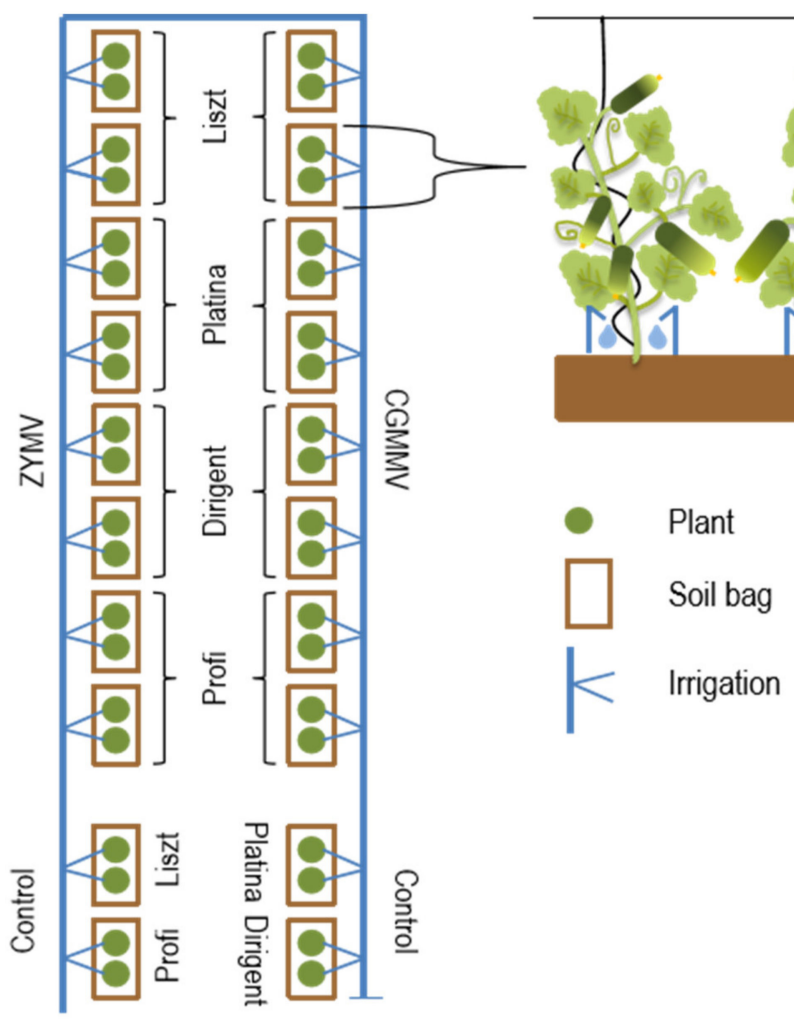

Figure 1. Cultivation design for Cucumis sativus plants infected with Zucchini yellow mosaic virus (ZYMV) or Cucumber green mottle mosaic virus (CGMMV) and control. Plants were cultivated under greenhouse conditions in soil bags; water was supplied via drip irrigation. Two plants of each cultivar ('Platina', 'Liszt', 'Dirigent' and 'Profi') served as controls. Four plants per cultivar were infected with one of the viruses.

\subsection{Diagnosis of Virus Infection}

A visual assessment of phenotypic characteristics of all plants was carried out every two weeks to record the size and foliage of the plants as well as the occurrence of virus symptoms on leaves, flowers and fruits. The yield was recorded by number and weight of harvested fruits. Leaf material of all plants was tested for CGMMV and ZYMV using a serological assay before and after the harvest period. Stems of all fruits to be processed were tested separately (individual samples). ELISA (Double Antibody Sandwich Enzyme-linked Immunosorbent Assay) was performed using commercially available assays (RT-0190 and RT-0234) according to the supplier's instructions (DSMZ, Braunschweig, Germany). In deviation from that protocol, only $100 \mu \mathrm{L}$ aliquots per well were used instead of $200 \mu \mathrm{L}$. Each sample was tested with three replicates. The optical density of the samples at $405 \mathrm{~nm}$ was rated after 30 and $60 \mathrm{~min}$ substrate incubation. The cut-off value was defined as $($ mean $+3 \mathrm{~s}) \times 1.1$ with mean: mean value of control and s: standard deviation of control.

\subsection{Harvesting and Processing of Cucumber Fruits}

Cucumbers with a length of 6 to $9 \mathrm{~cm}$ were harvested at regular intervals of 2 to 3 days, beginning with the 7th week after sowing for six weeks. This length corresponds to the most commonly used sorting size for industrial preservation. The fruits were stored within $24 \mathrm{~h}$ at 10 and $12{ }^{\circ} \mathrm{C}$ until further processing. The cucumbers were placed separately in $150 \mathrm{~mL}$ jars and filled up with commercial gherkin vinegar solution with $1 \mathrm{~cm}$ space under the lid. The pasteurization was carried out with a water-filled automatic preserving cooker for $32 \mathrm{~min}$ to reach the target temperature of $82{ }^{\circ} \mathrm{C}$ starting at a water temperature of $35^{\circ} \mathrm{C}$. Three-quarters of the jars were covered with water. The core temperature of the fruits at the end of the process was approximately $77^{\circ} \mathrm{C}$. Finally, the jars were tightly closed and cooled 
down in a water bath of $30^{\circ} \mathrm{C}$ twice for $5 \mathrm{~min}$ before they were stored in dark conditions at 20 to $25^{\circ} \mathrm{C}$.

\subsection{Instrumental Measurement of Texture of Pasteurized and Fresh Cucumbers}

Firmness and crunchiness were measured to determine the texture quality. Texture measurements of fresh cucumbers were carried out within $48 \mathrm{~h}$ of harvest. Textures of stored pickles were measured four, six or 12 months after harvest. The measurements were performed with a texture analyzer TA.XT plus (Stable Micro Systems Ltd., Godalming, UK) with a Warner Bratzler rectangular notch blade (Stable Micro Systems Ltd., Godalming, UK). The feed speed of the blade was $1 \mathrm{~mm} / \mathrm{s}$. Due to the decreasing texture hardness from the stem to the flower of the cucumber [29], a cross-sectional $1 \mathrm{~cm}$ thick slice was always cut from the middle of each cucumber using a double-blade knife and placed horizontally in the measuring cell. The Exponent Connect Software (Stable Micro Systems Ltd., Godalming, UK) recorded the force-displacement curve and reported the maximum shear force (firmness, N/mm) and the rise of the graph from $20 \%$ to $80 \%$ of maximum shear force (crunchiness, $\mathrm{N} / \mathrm{mm}^{2}$ ). Since the texture quality decreases with the increasing size of the cucumber, the calculations were based on the diameter of the cucumber slice. Statistical analysis was completed with GraphPad Prism 8 (GraphPad Software, San Diego, CA, USA) based on Analysis of Variance (ANOVA).

\subsection{Light Microscopy}

\subsubsection{Sample Preparation and Sectioning}

Sample preparation was performed using slightly modified standard methods [30-32]. Cross-sectional cucumber slices of approximately $10 \mathrm{~mm}$ thickness were immersed in an adequate volume of a FAA (formalin-acetic acid-alcohol) fixative with a final concentration of $63 \%$ ethanol, $5 \%$ acetic acid and $2 \%$ formaldehyde for one week. After fixation, the samples were washed in $70 \%$ ethanol three times for five minutes and then kept in the same medium at $4{ }^{\circ} \mathrm{C}$ until further processing. Thereafter, FAA-fixed samples were transferred into Rotilabo ${ }^{\circledR}$-embedding cassettes (Carl Roth GmbH + Co. KG, Karlsruhe, Germany) and subsequently dehydrated and infiltrated with paraffin wax (Surgipath Paraplast, Leica Biosystems, Nußloch, Germany) using an automated tissue processor (Hypercenter ${ }^{\circledR} \mathrm{XP}$, Shandon Scientific Limited, Runcorn, UK). Dehydration was performed by an ascending ethanol series (80\%, 92\% per one hour and $4 \times 96 \%, 100 \%, 2 \mathrm{~h}$ each) and a final incubation in 100\% 2-propanol for two hours. This was followed by two steps ( 2 and $3 \mathrm{~h}$ ) in a clearing agent (Roticlear ${ }^{\circledR}$, Carl Roth $\mathrm{GmbH}+$ Co. KG, Karlsruhe Germany) in order to remove any alcohol from the samples. The final infiltration was performed in two steps ( 3 and $5 \mathrm{~h}$ ) with paraffin from different wax baths to avoid contamination of the tissue with the remaining clearing agent. All steps in the automated tissue processor took place under a vacuum. Finally, the paraffin impregnated samples were manually embedded by using the EG 1160 Paraffin Embedding Center (Leica Microsystems GmbH, Wetzlar, Germany). Sectioning was performed with a microtome Microm HM 355S (Thermo Fisher Scientific, Waltham, MA, USA) equipped with microtome blades S35 (FEATHER Safety Razor Co., Ltd., Osaka, Japan). The obtained sections of $10 \mu \mathrm{m}$ thickness were mounted on microscope slides coated with protein glycerol (Carl Roth GmbH + Co. KG, Karlsruhe, Germany) to improve adhesion.

\subsubsection{Staining and Image Recording}

Microtome sections were deparaffinized using the non-toxic xylene substitute Roti ${ }^{\circledR}$ Histol $(3 \times 5 \mathrm{~min})$. After washing in 100\% 2-propanol for two minutes, slices were rehydrated in a descending ethanol series (96\%, 80\%, 70\%, 50\% for 2 min each). Afterward, sections were stained with fuchsin-chrysoidine-astra blue (FCA) according to Etzold (MORPHISTO ${ }^{\circledR} \mathrm{GmbH}$, Offenbach am Main, Germany) for $8 \mathrm{~min}$. FCA was used to stain cell walls for better contrast during microscopy. The excess staining solution was removed by rinsing with ddH2O, and the sections were dehydrated again by briefly dipping the 
slides into an ascending ethanol series (40\%, 70\%, 96\%). After two final immersions in $100 \%$ 2-propanol, slides with the sections were immersed twice for at least two minutes into Roti ${ }^{\circledR}$-Histol for clearing. Thereafter, before the clarifying agent had completely evaporated, a few drops of the embedding medium Roti ${ }^{\circledR}$ Histokitt (Carl Roth GmbH + Co. KG, Karlsruhe, Germany) were added to each slide, and a coverslip was applied. Finally, the embedding medium was allowed to harden for at least one day. The microscopy was performed at a $400 \times$ magnification with the Axioskop 40 FL (Carl Zeiss Microscopy GmbH, Jena, Germany). Images were captured with the AxioCam MRc (Carl Zeiss Microscopy $\mathrm{GmbH}$, Jena, Germany) and processed with the associated software ZEN 2.5 (blue Edition) (Carl Zeiss Microscopy GmbH, Jena, Germany).

\section{Results}

\subsection{Virus Induced Phenotypic Symptoms on Plants and Fruits}

The first characteristic virus symptoms appeared 14 days after mechanical inoculation. In particular, ZYMV-infected plants showed deformations, blistering, chlorosis and mosaic on the leaves throughout the growing season (Figure 2F). These plants developed small leaves $(<8 \mathrm{~cm}$ length) and a reduced formation of side shoots (Figure $2 \mathrm{C}$ ). Almost all fruits showed severe symptoms indicated by deformations, pox-like growths and discoloration (Figure 2I). Severe deformations of these fruits hampered their subsequent pasteurization as they do not fit to the limited glass diameter of $3 \mathrm{~cm}$. In contrast, CGMMV-infected plants showed mild virus symptoms like mottling and vein brightening on young leaves (Figure 2E). Slight leaf deformation and blistering could be observed in some cases. The symptoms were no longer visible in fully developed leaves. The general appearance of CGMMV-infected plants (Figure 2B) was comparable to the control (Figure 2A,D,G); fruits also showed no visible virus induced symptoms (Figure $2 \mathrm{H}$ ). The degree of expression and appearance of virus induced symptoms were the same for all cultivars.

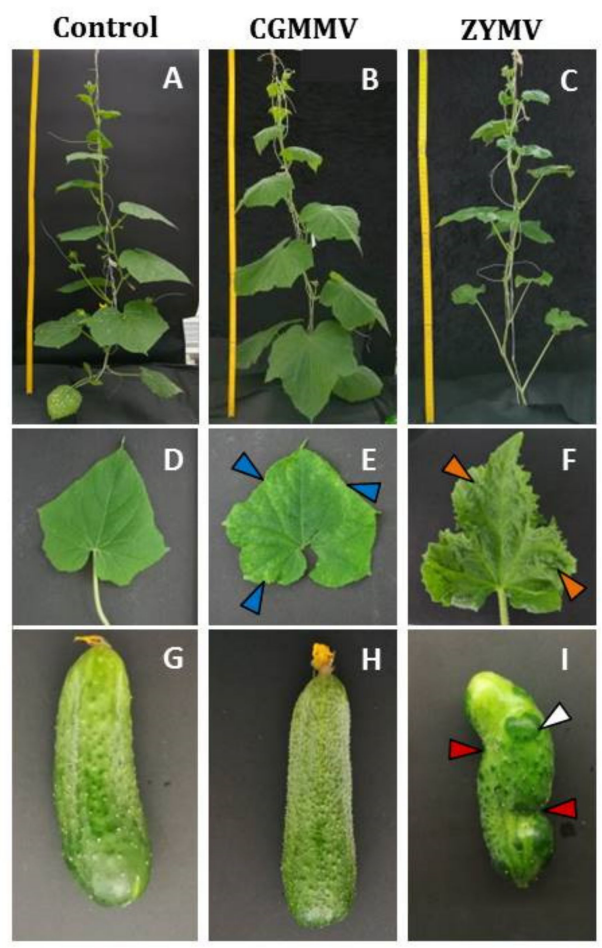

Figure 2. Macroscopic effect of CGMMV and ZYMV in C. sativus. Control plants show a healthy appearance (A,D,G). Plant growth (B) and fruit appearance $(\mathbf{H})$ of CGMMV-infected plants were comparable to control. On leaves (E) soft mottling (blue arrow heads) could be observed. ZYMV-infected plants showed small leaves (C), blistering (orange arrow heads) and deformation on leaves (F) as well as malformation (red arrow heads), proliferation (white arrow head) and discoloration of fruits (I). 


\subsection{Yield and Influence of Plant Viruses}

Over a period of six weeks, 447 cucumbers with a total weight of $13.89 \mathrm{~kg}$ were harvested from the 40 cultivated plants. The number of harvested and processed cucumbers is listed in Table 1. The differences between harvested and processed fruit numbers resulted from fruits discarded due to their size or severe deformations or when the texture was measured after harvest or used as a sample for ELISA.

Table 1. Number of harvested and processed cucumbers, sorted by cultivar, virus infection Zucchini yellow mosaic virus (ZYMV), Cucumber green mottle mosaic (CGMMV)) and control.

\begin{tabular}{lccccc}
\hline & \multirow{2}{*}{ Virusinfection } & \multicolumn{4}{c}{ Cultivar } \\
\cline { 3 - 6 } & & Liszt & Platina & Profi & Dirigent \\
\hline \multirow{2}{*}{ Harvested } & CGMMV & 67 & 75 & 59 & 50 \\
cucumbers & ZYMV & 19 & 40 & 26 & 16 \\
& control & 43 & 14 & 24 & 14 \\
\hline \multirow{2}{*}{ Processed } & CGMMV & 50 & 53 & 47 & 38 \\
cucumbers & ZYMV & 13 & 27 & 12 & 7 \\
& control & 29 & 9 & 19 & 11 \\
\hline
\end{tabular}

Harvest of ZYMV-infected plants had been delayed by seven days due to delayed flowering. An ANOVA revealed that both plant viruses affected the number of fruits per plant and weight per fruit independent of the cultivar. ZYMV infection resulted in a significant reduction in fruit number per plant and weight loss per fruit in all cultivars. Due to ZYMV-infection, the fruits per plant were reduced to 6.31 fruits / plant, a reduction of $53.6 \%$ ( $p$-value $=0.0073$, ANOVA $)$ in comparison to the control with 13.57 fruits $/$ plant, and of $59.8 \%$ in comparison to CGMMV (15.68 fruits/plant, $p$-value $<0.0001$, ANOVA). The number of fruits per plant of CGMMV-infected plants increased by $15.6 \%$ in comparison to control ( $p$-value $=0.6183$, ANOVA). One of the two control plants of the cultivar 'Dirigent produced no fruits during the harvest period. Therefore, the number of fruits could only refer to one plant. There is no obvious explanation for the low number of cucumbers harvested from control plants 'Platina'. Three weeks after the start of harvesting, CGMMV contamination was detected in one of the 'Profi'-control plants; thus, all contaminated cucumbers of this plant were not considered for further analysis. An average ZYMVinfected cucumber measured $27.98 \mathrm{~g}$ and was $16.55 \%$ lighter than control fruits, whereas CGMMV-infected cucumbers were slightly $(4.06 \%)$ heavier than control fruits. An ANOVA revealed that both plant viruses affected fruit weight independent of the cultivar (see Figure 3). Graphs showing texture values of the individual cultivars in comparison can be found in Appendix A, Figure A1.

\subsection{Virus Detection by Serological Assay}

All plants artificially inoculated with CGMMV and ZYMV tested positive three weeks after inoculation. The control plants tested negative for both viruses before and after harvest. The fruits of one control plant of cultivar 'Profi' tested positive for CGMMV three weeks after harvest started. Those fruits were discarded instead of including them in the yield calculation and further processing. For the entire period of the experiment, fruits from CGMMV and ZYMV infected plants serologically tested positive, confirming a systemic spread of the virus within the plants. No cross-contamination of virus variants in infected plants occurred. 
A

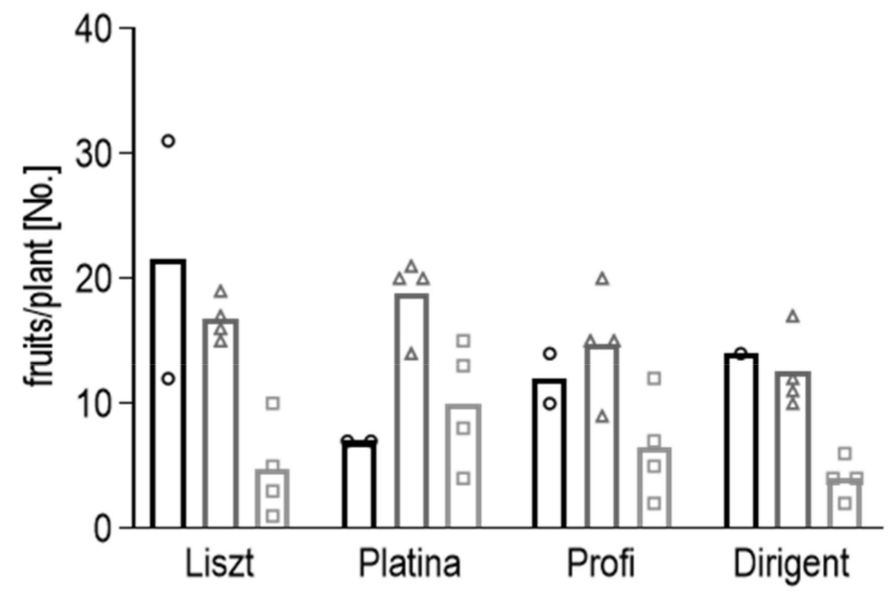

C

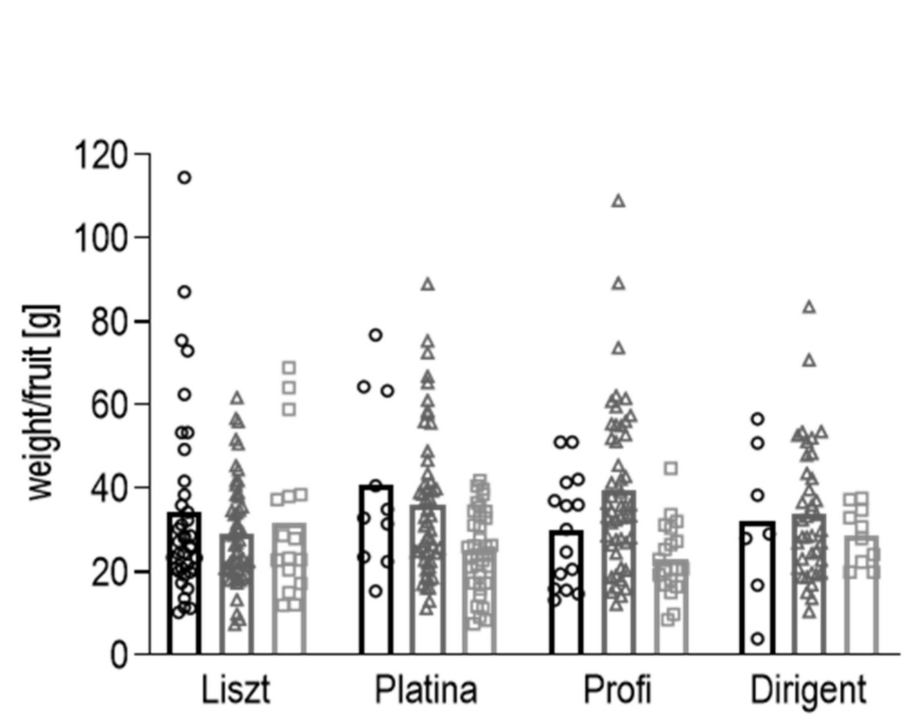

B

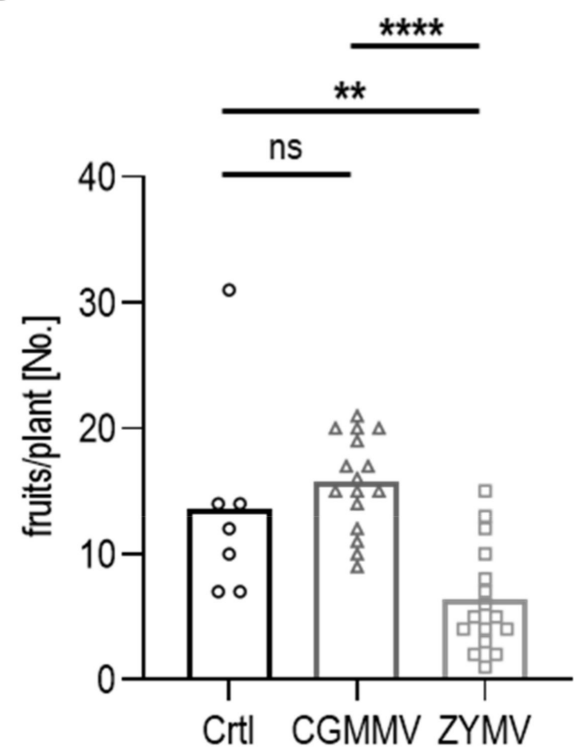

D

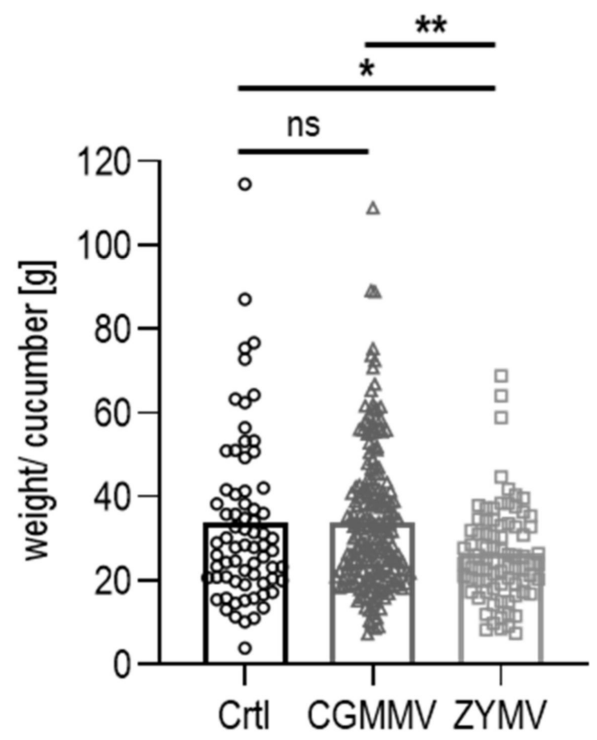

Figure 3. Yield per C. sativus plant (fruit/plant) and weight per fruit. The plants were infected with CGMMV or ZYMV and cultivated under greenhouse conditions. The impact of the viruses on the number of fruits per plant $(\mathbf{A}, \mathbf{B})$ and their weight (C,D) is independent of the cultivar. No significant differences between the cultivars ('Liszt', 'Platina', 'Profi', 'Dirigent') were found between the control plants. These viruses each have a significant influence on the number of fruits (B) and their weight (D) in general. The plant numbers per cultivar were $n=4$ for infected plants per virus variant. The numbers of control plants per cultivar were $\mathrm{n}=2$ with the exception of cultivar 'Dirigent' with $\mathrm{n}=1$. The numbers of harvested fruits for control plants per cultivar were as follows: 'Liszt' $n=43$, 'Platina' $n=14$, 'Profi' $n=24$ and 'Dirigent' $n=14^{\prime}$. The numbers of harvested fruits for CGMMV-infected plants per cultivar were as follows: 'Liszt' $\mathrm{n}=67$, 'Platina' $\mathrm{n}=75$, 'Profi' $\mathrm{n}=59$ and 'Dirigent' $\mathrm{n}=50$ '. The numbers of harvested fruits for ZYMV-infected plants per cultivar were as follows: 'Liszt' $\mathrm{n}=19$, 'Platina' $\mathrm{n}=40$, 'Profi' $\mathrm{n}=26$ and 'Dirigent' $\mathrm{n}=16^{\prime}$. ANOVA was performed with $\mathrm{ns} p>0.05,{ }^{*} p \leq 0.05,{ }^{* *} p \leq 0.01$, $* * * * p \leq 0.0001$. 


\subsection{Measurement of Firmness and Crunchiness}

Texture measurements were carried out with fresh and pasteurized pickles. The measurements were performed for each cultivar infected with either the plant virus CGMMV or ZYMV and compared to control. Each cucumber represented one sample unit. Due to severe deformations and a comparatively low number of fruits of ZYMV-infected plants and control plants, texture measurements were focused on four-month stored pickles. Texture measurements of pasteurized pickles after six months of storage included six ZYMV-infected cucumber samples of the cultivars 'Platina' and 'Liszt' and a total of 15 fruits of control plants of the cultivars 'Liszt', 'Profi' and 'Platina'. Texture measurements after 12 months of storage included samples of all cultivars for virus-infected and control plants. The individual cucumber cultivars were grouped together on the basis of comparable average texture values; all following figures summarize the texture values of the cultivars and represent them by the type of virus infection and control. Graphs showing texture values of the individual cultivars in comparison can be found in Appendix A, Figure A1.

\subsubsection{Texture of Fresh Cucumber Fruits}

Texture measurements of freshly harvested cucumbers were carried out within $48 \mathrm{~h}$ of harvest. Sixty fresh cucumbers were analysed for texture, hence for the control $n=15$, CGMMV-infection $n=30$ and ZYMV-infection $n=15$. As shown in Figure 4, neither crunchiness (B) nor firmness (A) of fresh, unprocessed cucumbers showed significant differences between virus-infected cucumbers and the control. The texture values of CGMMV-infected cucumbers $\left(2.479 \mathrm{~N} / \mathrm{mm} ; 0.975 \mathrm{~N} / \mathrm{mm}^{2}\right)$ tended to be higher than the values of ZYMVinfection $\left(2.276 \mathrm{~N} / \mathrm{mm} ; 0.876 \mathrm{~N} / \mathrm{mm}^{2}\right)$ and control $\left(2.375 \mathrm{~N} / \mathrm{mm} ; 0.844 \mathrm{~N} / \mathrm{mm}^{2}\right)$. The high scatter of both measurement parameters in virus-infected cucumbers, especially in ZYMV-infected cucumbers, is caused by the varying intensity of fruit changes caused by the viruses. The graphs of the texture values of the individual cultivars (Appendix A, Figure A1) show a reduction in crunchiness for CGMMV-infected 'Platina' and 'Dirigent' cultivars compared to 'Liszt' and a difference between control fruits of 'Liszt' and 'Profi'.

A

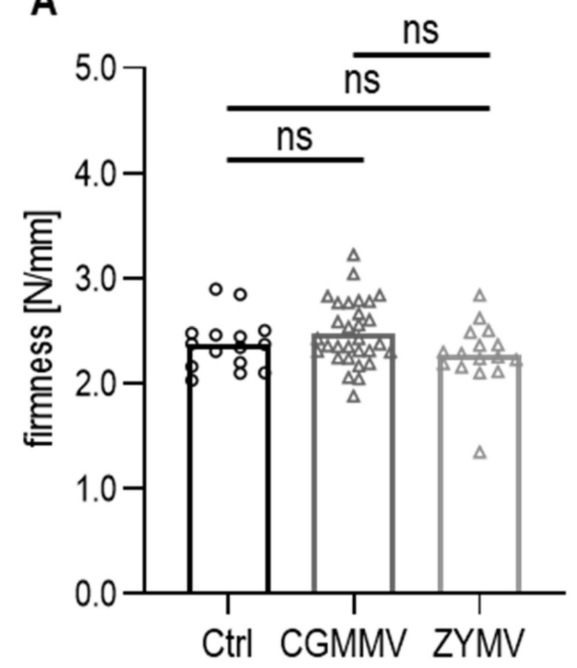

B

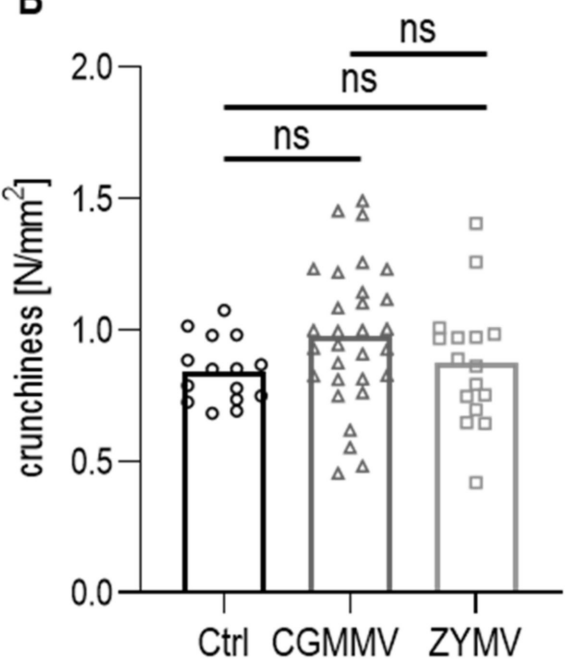

Figure 4. Comparison of the texture of virus-infected and non-infected C. sativus fruits shown by firmness $(\mathrm{N} / \mathrm{mm})(A)$ and crunchiness $\left(\mathrm{N} / \mathrm{mm}^{2}\right)($ B $)$ of freshly harvested cucumbers. There are no significant differences between the control fruits (Ctrl, $n=15)$, CGMMV-infected $(n=30)$ and ZYMV-infected $(\mathrm{n}=15)$ cucumbers. ANOVA was performed with ns $p>0.05$. 


\subsubsection{Texture of Pasteurized Pickles}

Textures of pasteurized and stored pickles were measured four, six or 12 months after harvest (Figure 5). Since pickled cucumbers are a natural product, general variability in texture values, even compared to fresh cucumbers, is to be expected. In general, crunchiness is reduced as storage progresses. Pickles infected with a plant virus decreased in firmness over the storage period of 12 months. A general loss in texture was more pronounced in pickles infected with ZYMV. A correlation between firmness and crunchiness was noted for all time points. The crunchiness and firmness of ZYMV-infected pickles are significantly reduced at all times compared to CGMMV-infected and control pickles. This difference was most evident after six months, with a decrease in texture values of about $55 \%$. Up to final measurement after 12 months, texture quality of ZYMV-infected cucumbers decreased by another $20 \%$ compared to control. The graphs of the texture values of the individual cultivars (Appendix A, Figure A1) show differences regarding crunchiness between CGMMV-infected 'Platina' and 'Dirigent' fruits compared to 'Liszt' at the measurement time points after four and six months of storage (as already occurred in the fresh cucumbers). After 12 months of storage, slight differences were evident between the firmness of control fruit of 'Liszt', 'Platina' and 'Profi'.
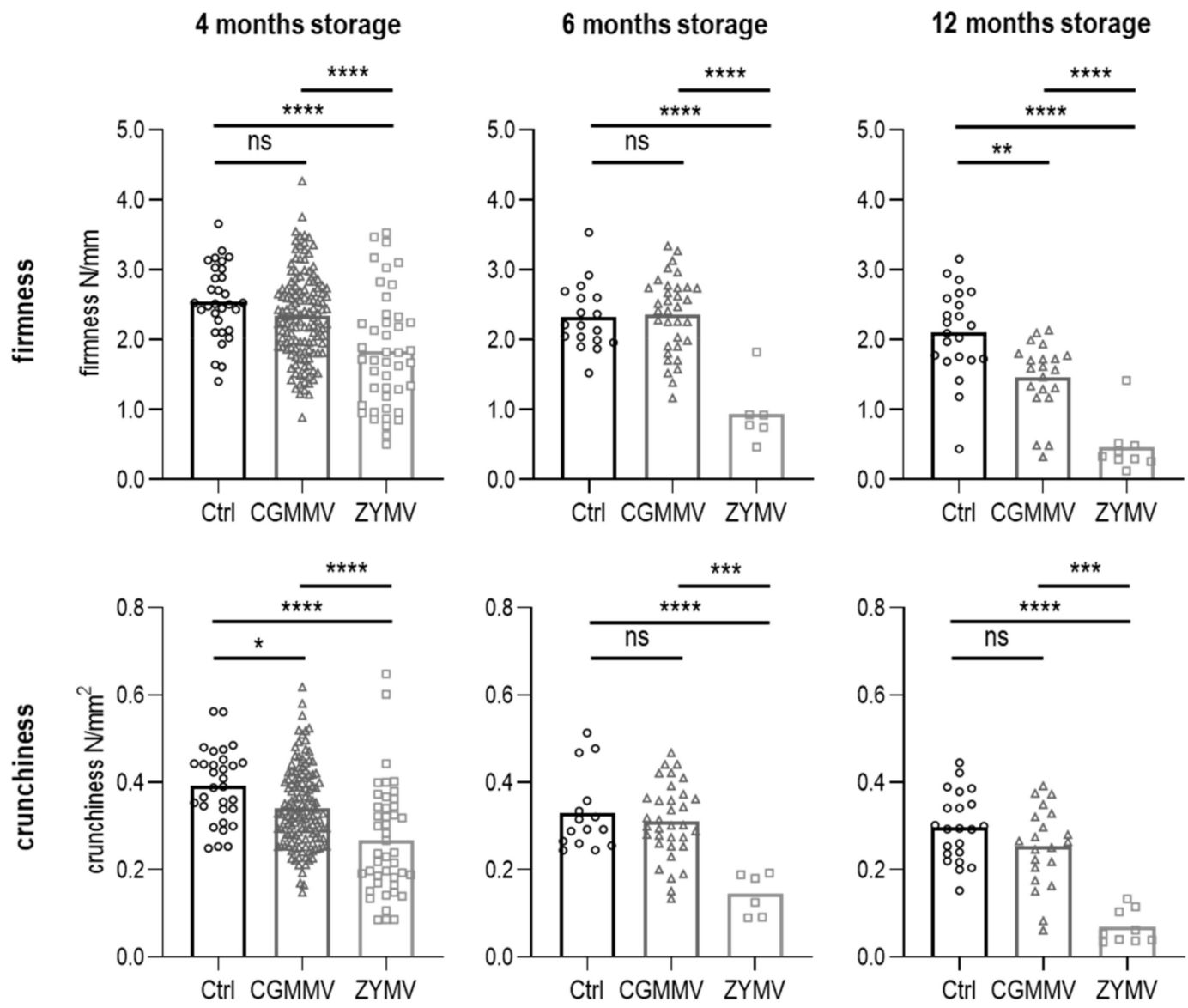

Figure 5. Crunchiness and Firmness of virus-infected and non-infected pasteurized C. sativus fruits stored for four, six and 12 months. The texture values of control fruits (Ctrl) and CGMMV-infected fruits are approximately the same magnitude, except for firmness after 12 months of storage. The texture values of ZYMV-infected pickles are consistently significantly lower than the values of control and CGMMV-infected fruits (ANOVA). The numbers of measured control fruits were as follows: after four months, $n=31$, after six months, $n=18$, after 12 months $n=22$. The numbers of measured CGMMVinfected fruits were as follows: after four months, $n=133$, after six months $n=34$, after 12 months $n=21$. The numbers of measured ZYMV-infected fruits were as follows: after four months, $\mathrm{n}=44$, after six months $\mathrm{n}=6$, after 12 months $\mathrm{n}=9$. ANOVA was performed with ns $p>0.05,{ }^{*} p \leq 0.05,{ }^{* *} p \leq 0.01,{ }^{* * *} p \leq 0.001,{ }^{* * * *} p \leq 0.0001$. 


\subsection{Histological Alterations}

Cell structures of pasteurized CGMMV-, ZYMV-infected, and control cucumbers ( $n=3$ each) were analyzed in stained microtome sections by microscopic means. The cucumbers had a comparable thickness $(1.8$ to $1.9 \mathrm{~cm})$ and length $(6.9$ to $7.9 \mathrm{~cm})$. The parenchyma cells of ZYMV-infected cucumbers (Figure 6C) are distinctly enlarged, whereas cells of the epidermis appear shortened and thickened compared to the control (Figure 6A). CGMMV-infected cucumbers (Figure 6B) also showed shortened epidermal cells, whereas parenchyma cells were comparable to the control.

A

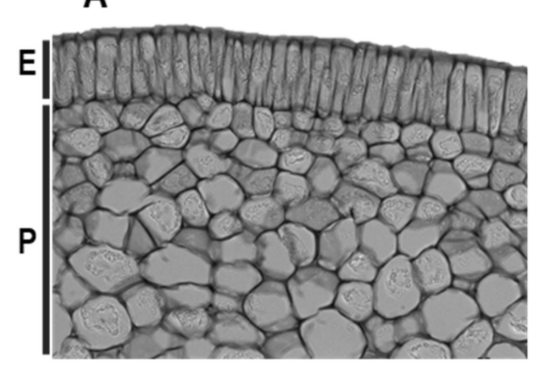

B

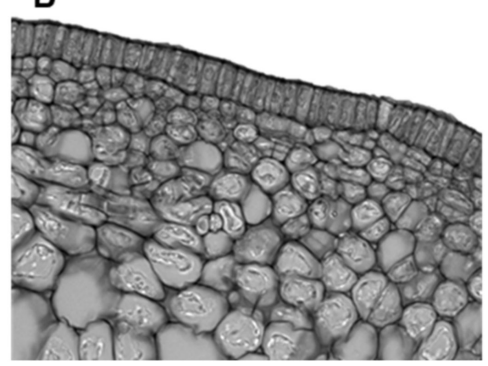

C

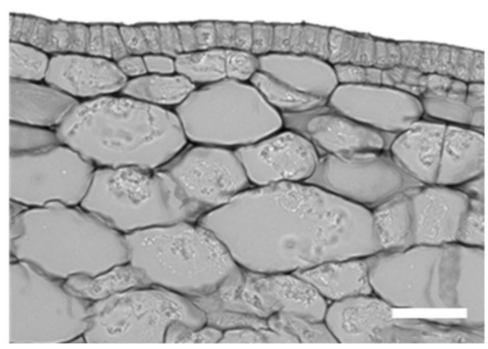

Figure 6. Light microscope images show $10 \mu \mathrm{m}$ cross-sections of control (A), CGMMV-infected (B) and ZYMV-infected (C) pasteurized C. sativus fruits of comparable size and age. ZYMV-infected parenchymal cells (P) are highly enlarged, whereas epidermal cells (E) show a shortened, thickened shape compared to control. The epidermal cells of CGMMV-infected cucumbers also appear smaller, whereas parenchymal tissue is comparable to the control. Scale bar $=40 \mu \mathrm{m}$.

\section{Discussion}

The texture is a key factor for the in-mouth perception of fruits and is decisively influenced by ripeness, juiciness and mealiness. Consumers prefer firm and crunchy pickles; thus, the softening of pickles could be a major drawback $[5,33]$. Softening of pickles is usually first detected by industry four to six months after the processing, even though the raw material was inconspicuous [34].

Knowledge about the influence of phytopathogenic viruses on fruit texture quality is missing, so the current hypothesis on viruses being an initiating or contributing factor of softening could neither be confirmed nor rejected. This was the first study to highlight the role of plant viruses in the context of softening pickles. Based on the current analysis, there may be a correlation between the severity of virus induced symptoms on fruits, cell structure alterations, and texture quality of pasteurized cucumbers. In this and other studies, a ZYMV-infection induced distinctly visible and severe symptoms such as blistering, strangling, mosaic and yellowing on cucumber leaves and fruits [26,35]. Simultaneously, light microscopy of fruit tissue revealed a massive structural change indicated by large swollen cells of parenchymal tissue and small thickened epidermal cells. In addition, a $50 \%$ softer and less crunchy texture of pasteurized cucumbers infected with ZYMV was measured compared to the control after six months of storage. The almost symptom-free fruits of CGMMV-infected cucumber plants did not reveal such significant deviations from the control, neither in fruit tissue structure nor in texture values. Differences in texture values between individual cultivars such as 'Liszt' and 'Platina' exist naturally, as studies have shown so far $[36,37]$. Pasteurization and long storage could amplify these differences and are thus clearly measurable even in the fresh or pasteurized state.

Textural properties are defined by the thickness of the epidermis, cell adhesion, size and shape of cells, turgor, and chemical composition or changes during processing [9]. In order to spread within the plant, the viruses depend highly on their host and might affect cell walls, membranes, metabolism and morphology of their host plant [38]. Proteome studies revealed that viruses affect major cell wall and membrane polysaccharides such as pectin, hemicellulose and cellulose. These numerous textural cell compounds can be degraded by virus-induced upregulation of corresponding enzymes like pectin 
methylesterase, which causes cell structures to become unstable, cell walls to become porous or the water regulation in the plants to be affected. Cell wall stabilizing elements such as calcium concentration can also be affected by a viral infection [39-43]. In our studies, we observed large swollen cells in ZYMV-infected cucumbers. Similar findings were observed in a previous study showing that ZYMV-related changes led to swollen cells with enlarged vacuoles and an increased number of larger intercellular cavities in young leaves of Curcubit pepo [44]. Other Potyviruses are also known to affect the texture of their host plants: Plum pox virus causes sharka disease in stone fruits, which induce a brownish or reddish necrotic flesh within the fruit [45]. A Sweetpotato feathery mottle virus infection can cause thinned palisade tissue without the normal columnar appearance, thickened spongy tissue, and irregular cell forms in sweet potato leaves [46]. These cellular changes were particularly observed in young plants or leaves. Cucumbers that are processed are also young, unripe fruits.

If these pre-damaged cucumbers with enlarged cells, disordered cell structure and possibly affected textural compounds are exposed to thermal stress during pasteurization, progressive texture reductions are conceivable. Heat modifies the pectin of parenchymatic fruits such as cucumber, making it even easier to rupture the middle lamella and reducing cell-cell adhesion [7,47]. Furthermore, enlarged cells and vacuoles indicate increased water retention. Cell stability also depends strongly on the turgor of cells, which decreases during heat treatment [7]. Cucumbers have higher texture values when the turgor is high [9]. Therefore, reduced turgor (of enlarged cells) results in a texture reduction [48]. In fresh, well-watered cucumbers, the turgor is stable; thus, we could not measure any texture change in such fruits.

A reduced number of chloroplasts due to ZYMV-infection leads to the typical yellow mosaic pattern and light green areas on leaves and fruits [35]. It has been shown that a reduced chlorophyll content due to low light intensity shortens the shelf-life of greenhousegrown long English cucumbers (Cucumis sativus L.) [49]. Thus, many factors influence the texture, and a combination of abiotic or further biotic and viral influences could induce softening. Abiotic factors such as available soil moisture, temperature, relative humidity and nutrients influence the texture directly by altering plant properties like organelles, metabolites, turgor and cell wall composition. For instance, water stress due to lack of water or high temperatures correlates directly with texture firmness through a reduction of turgor pressure or metabolism. [48] In carrots and cucumbers, an upregulation of polygalacturonase activity was observed due to lack of water, causing changes in cell wall component pectin and consequently softening [50-52].

Textural changes were already described in the fifties with fermented cucumbers in brine. Fungus-laden flowers attached to the cucumbers were considered to be an important source for softening, causing fungal polygalacturonases and cellulases [18,19]. So far, softening fungi or their enzymes could not be detected after the pasteurization of cucumbers. However, thermostable enzymes are still considered potential contributors to softening [20]. The inactivation of enzymes within the cucumber also depends strongly on the core temperature of the fruit, which in turn depends on the fruit diameter [53]. Virally damaged cell structures and components could be attack sites for respective enzymes.

In addition, infected crops often produce lower yields commonly enhanced by abiotic factors. The observed symptom severity of ZYMV-infected plants was reflected in the number of harvested cucumbers. Similar to Zechmann et al. [35], we found a seven-day delay in flowering harvesting ZYMV-infected plants compared to the control and CGMMVinfection. A ZYMV-infection can result in a yield reduction of 64-85\%, which corresponds to yield losses observed in this study, and up to 95\% when taking non-marketability of most of the fruits into consideration [54]. In contrast, CGMMV-infection caused a $15.6 \%$ increase in yield in this study, although yield losses of up to $15 \%$ in cucumber and much higher economic damage in other cucurbits with severe viral symptoms have been recorded in previous studies [27,55]. Prendelville et al. [56] assumed that a mild symptom expression is caused by an enhanced tolerance of the plant to the infection. It is also known that viruses 
causing disease in some plant species can be asymptomatic in others, especially under different environmental conditions [57].

CGMMV and ZYMV can be easily transferred mechanically, which is particularly problematic in the case of manual cucumber harvesting. The use of the same harvester on different fields and the close proximity of cucurbit crops like in the Spreewald region may facilitate the spread of plant viruses. In addition, ZYMV and CGMMV can be transmitted through vectors such as aphids, seeds, irrigation systems and soil [26,27]. The worldwide trade of seeds, plants and products also promotes global spread. Although ZYMV causes distinct symptoms and allows easy elimination of the infected fruits, certain cucumbers could still be marketed. Even cucumbers with macroscopically less visible symptoms can be biochemically affected. Furthermore, environmental conditions can contribute to different degrees of symptom expression or mask them. Since the plant viruses we addressed in our study are easily transmitted mechanically from plant to plant, strict sanitary measures and monitoring were required to avoid spreading throughout the crop.

We conclude that a cascade of pre- and postharvest influences of phytopathogenic viruses together with other biotic or even abiotic factors would be a conceivable cause for softening of pasteurized cucumbers. There seems to be a correlation between the intensity of external and internal induced symptoms of different viruses and the softening of pickle texture. We showed that ZYMV contributes to softening of pasteurized cucumbers. The texture reduction is probably based on virus-mediated enzymatic changes of structural components or decreasing turgor in morphologically affected cells. Further research at the cellular level on the relationship between virus titer and texture influence and on the interaction with other microorganisms is needed to bring the role of plant viruses in terms of softening of pickles to light.

Author Contributions: Conceptualization, A.-K.K. and M.B.; data curation, A.-K.K.; formal analysis, A.-K.K.; funding acquisition, P.L.; investigation, A.-K.K.; methodology, A.-K.K., S.S., P.M. (Peter Meurer) and P.M. (Peer Martin); project administration, P.M. (Peter Meurer); resources, C.B.; supervision, M.B. and C.B.; visualization, A.-K.K.; writing—original draft, A.-K.K.; writing-review \& editing, M.B. and P.L. All authors have read and agreed to the published version of the manuscript.

Funding: This research was funded by the European agricultural fund for rural development (EAFRD) (project number 204016000007/80168354).

Acknowledgments: We thank Nunhems Germany GmbH for providing cucumber seeds of the cultivar 'Platina', Graines Voltz for providing cultivar 'Profi', Rijk Zwaan Welver GmbH for providing cultivar 'Liszt' and 'Dirigent'. We thank Andrea Klinke, Gabriele Buddruss and Robert Winkler for their methodical support of the experiment and Saranya Kanukollu for editing and proofreading.

Conflicts of Interest: The funders had no role in the design of the study; in the collection, analysis, or interpretation of data; in the writing of the manuscript, or in the decision to publish the results. The authors declare no conflict of interest. 


\section{Appendix A}
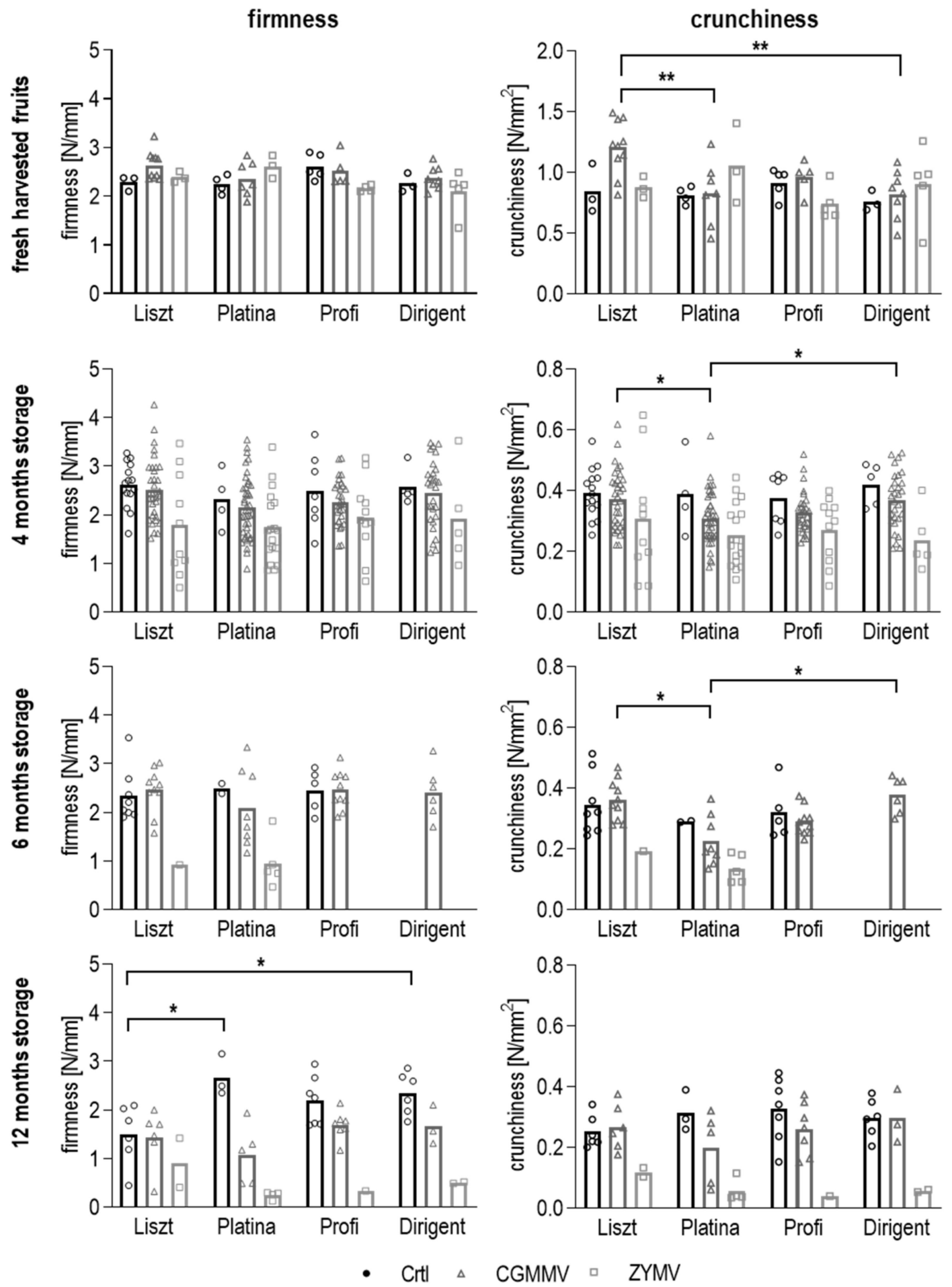

Figure A1. Texture of pasteurized and fresh Cucumis sativus fruits sorted by cultivar. The cucumbers were stored for four, six or 12 months after pasteurization. The cucumbers were harvested from plants with Cucumber green mottle mosaic virus (CGMMV), Zucchini yellow mosaic virus (ZYMV) infection or control plants. The cultivars 'Liszt', 'Platina', 'Profi' and 'Dirigent' were used. Firmness $(\mathrm{N} / \mathrm{mm})$ and crunchiness $(\mathrm{N} / \mathrm{mm} 2)$ were measured. ANOVA was performed with ${ }^{*} p \leq 0.05,{ }^{* *} p \leq 0.01$. 


\section{References}

1. Pal, S.; Sharma, H.R.; Thakur, A.K.; Dogra, R.K. Morpho-agronomic characterization of cucumber (Cucumis sativus L.) germplasm through principal component analysis. J. Pharmacogn. Phytochem. 2018, 7, 2573-2577.

2. Sebastian, P.; Schaefer, H.; Telford, I.R.H.; Renner, S.S. Cucumber (Cucumis sativus) and melon (C. melo) have numerous wild relatives in Asia and Australia, and the sister species of melon is from Australia. Proc. Natl. Acad. Sci. USA 2010, 107, 14269-14273. [CrossRef] [PubMed]

3. Breene, W.M.; Chou, H.; Davis, D.W. Texture profile analysis of cucumbers. J. Food Sci. 1972, 37, 113-117. [CrossRef]

4. Sahoo, M.; Prakash, J. Formulation and standardization of dill based gherkin pickles: A study on physico-chemical and sensory attributes. Indian J. Nutr. Diet. 2017, 54. [CrossRef]

5. Dupas de Matos, A.; Marangon, M.; Magli, M.; Cianciabella, M.; Predieri, S.; Curioni, A.; Vincenzi, S. Sensory characterization of cucumbers pickled with verjuice as novel acidifying agent. Food Chem. 2019, 286, 78-86. [CrossRef] [PubMed]

6. Demain, A.L.; Phaff, H.J. Softening of cucumbers during curing. J. Agric. Food Chem. 1957, 5, 60-64. [CrossRef]

7. Reeve, R.M. Relationships of histological structure to texture of fresh and processed fruits and vegetables. J. Texture Stud. 1970, 1, 247-284. [CrossRef]

8. Szczesniak, A.S.; Ilker, R. The meaning of textural characteristics-Juiciness in plant foodstuffs. J. Texture Stud. 1988, 19, 61-78. [CrossRef]

9. Sajnín, C.; Gamba, G.; Gerschenson, L.N.; Rojas, A.M. Textural, histological and biochemical changes in cucumber (Cucumis sativus L) due to immersion and variations in turgor pressure. J. Sci. Food Agric. 2003, 83, 731-740. [CrossRef]

10. Li, J.; Yu, J.; Chang, Y.; Xu, X.; Nie, S. Influences of high temperature stress on membrane permeability and activity of cell defence enzymes in leaves of cucumber seedlings. J. Changjiang Veg. 2007, 9, 59-61.

11. Alsadon, A.; Al-Helal, I.; Ibrahim, A.; Abdel-Ghany, A.; Al-Zaharani, S.; Ashour, T. The effects of plastic greenhouse covering on cucumber (Cucumis sativus L.) growth. Ecol. Eng. 2016, 87, 305-312. [CrossRef]

12. Bell, T.A.; Etchells, J.L. Influence of salt (NaCI) on pectinolytic softening of cucumbers. J. Food Sci. 1961, 26, 84-90. [CrossRef]

13. Mcfeeters, R.F.; Fleming, H.P. pH effect on calcium inhibition of softening of cucumber mesocarp tissue. J. Food Sci. 1991, 56, 730-732. [CrossRef]

14. Bell, T.A.; Turney, L.J.; Etchells, J.L. Influence of different organic acids on the firmness of fresh-pack pickles. J. Food Sci. 1972, 37, 446-449. [CrossRef]

15. Mcfeeters, R.F.; Fleming, H.P. Effect of calcium-ions on the thermodynamics of cucumber tissue softening. J. Food Sci. 1990, 55, 446-449. [CrossRef]

16. Sistrunk, W.A.; Kozup, J. Influence of processing methodology on quality of cucumber pickles. J. Food Sci. 1982, 47, 949-953. [CrossRef]

17. Thompson, R.L.; Fleming, H.P.; Monroe, R.J. Effects of storage-conditions on firmness of brined cucumbers. J. Food Sci. 1979, 44, 843-846. [CrossRef]

18. Etchells, J.L.; Bell, T.A.; Monroe, R.J.; Masley, P.M.; Demain, A.L. Populations and softening enzyme activity of filamentous fungi on flower, ovaries, and fruit of pickling cucumbers. Appl. Microbiol. 1958, 6, 427-440. [CrossRef]

19. Raymond, F.L.; Etchells, J.L.; Bell, T.A.; Masley, P.M. Filamentous fungi from blossoms, ovaries, and fruit of pickling cucumbers. Mycologia 1959, 51, 492-511. [CrossRef]

20. Voldřich, M.; Horsáková, I.; Čeřovský, M.; Čížková, H.; Opatová, H. Factors affecting the softening of pickled pasteurised cucumbers. Czech J. Food Sci. 2009, 27, 314-318. [CrossRef]

21. Zhao, J.; Zhang, X.; Hong, Y.; Liu, Y. Chloroplast in plant-virus interaction. Front. Microbiol. 2016, 7, 1565. [CrossRef] [PubMed]

22. Mauck, K.E.; De Moraes, C.M.; Mescher, M.C. Biochemical and physiological mechanisms underlying effects of Cucumber mosaic virus on host-plant traits that mediate transmission by aphid vectors. Plant Cell Environ. 2014, 37, 1427-1439. [CrossRef] [PubMed]

23. Ainsworh, G.C. Mosaic disease of cucumber. Ann. Appl. Biol. 1935, 22, 55-67. [CrossRef]

24. Lisa, V.; Boccardo, G.; Dagostino, G.; Dellavalle, G.; Daquilio, M. Characterization of a potyvirus that causes zucchini yellow mosaic. Phytopathology 1981, 71, 667-672. [CrossRef]

25. Lovisolo, O. Virus and viroid diseases of cucurbits. Acta Hortic. 1980. [CrossRef]

26. Desbiez, C.; Lecoq, H. Zucchini yellow mosaic virus. Plant Pathol. 1997, 46. [CrossRef]

27. Dombrovsky, A.; Tran-Nguyen, L.T.T.; Jones, R.A.C. Cucumber green mottle mosaic virus: Rapidly increasing global distribution, etiology, epidemiology, and management. Annu. Rev. Phytopathol. 2017, 55, 231-256. [CrossRef]

28. Kersten, A.-K.; Scharf, S.; Bandte, M.; Meurer, P.; Lentzsch, P.; Büttner, C. Influence of plant viruses on the texture of fresh and processed fruits of Cucumis sativus. In Proceedings of the 4th International Symposium on Horticulture in Europe, Stuttgart, Germany (Online), 9-11 March 2021.

29. Thompson, R.L.; Fleming, H.P.; Hamann, D.D.; Monroe, R.J. Methode for determination of firmness in cucumber slices. J. Texture Stud. 1982, 13, 311-324. [CrossRef]

30. Fowke, L.C.; Rennie, P.J. Botanical microtechnique for plant cultures. In Plant Cell, Tissue and Organ Culture; Springer: Berlin/Heidelberg, Germany, 1995; pp. 217-228.

31. Soukup, A.; Tylová, E. Essential methods of plant sample preparation for light microscopy. In Plant Cell Morphogenesis; Springer: Berlin/Heidelberg, Germany, 2014; Volume 1992, pp. 1-23. 
32. Gamborg, O.; Phillips, G.C. Plant Cell, Tissue and Organ Culture: Fundamental Methods; Springer Science \& Business Media: Berlin/Heidelberg, Germany, 2013.

33. Zubkova, K.; Stoianova, O. Study of quality of snack gherkin tinned food. EUREKA Life Sci. 2020, 1, 25-31. [CrossRef]

34. Thöne, M. (Obst- und Gemüseverarbeitung Spreewaldkonserve Golßen GmbH, Golßen, Brandenburg, Germany). Personal communication, 2019.

35. Zechmann, B.; Muller, M.; Zellnig, G. Cytological modifications in zucchini yellow mosaic virus (ZYMV)-infected Styrian pumpkin plants. Arch. Virol. 2003, 148, 1119-1133. [CrossRef]

36. Suojala-Ahlfors, T.J.H. Fruit firmness of pickling cucumber cultivars. HortTechnology 2005, 15, 777-781. [CrossRef]

37. Shimomura, K.; Horie, H.; Sugiyama, M.; Kawazu, Y.; Yoshioka, Y.J.S.H. Quantitative evaluation of cucumber fruit texture and shape traits reveals extensive diversity and differentiation. Sci. Hort. 2016, 199, 133-141. [CrossRef]

38. Malmstrom, C.M.; Melcher, U.; Bosque-Perez, N.A. The expanding field of plant virus ecology: Historical foundations, knowledge gaps, and research directions. Virus Res. 2011, 159, 84-94. [CrossRef] [PubMed]

39. Alexander, M.M.; Cilia, M. A molecular tug-of-war: Global plant proteome changes during viral infection. Curr. Plant Biol. 2016, 5, 13-24. [CrossRef]

40. Carmo, L.S.; Resende, R.O.; Silva, L.P.; Ribeiro, S.G.; Mehta, A. Identification of host proteins modulated by the virulence factor AC2 of Tomato chlorotic mottle virus in Nicotiana benthamiana. Proteomics 2013, 13, 1947-1960. [CrossRef] [PubMed]

41. Chen, M.-H.; Sheng, J.; Hind, G.; Handa, A.K.; Citovsky, V. Interaction between the tobacco mosaic virus movement protein and host cell pectin methylesterases is required for viral cell-to-cell movement. EMBO J. 2000, 19, 913-920. [CrossRef] [PubMed]

42. Brizard, J.P.; Carapito, C.; Delalande, F.; van Dorsselaer, A.; Brugidou, C. Proteome analysis of plant-virus interactome: Comprehensive data for virus multiplication inside their hosts. Mol. Cell. Proteom. 2006, 5, 2279-2297. [CrossRef]

43. Kofalvi, S.A.; Gao, J.-G.; Nassuth, A. Biochemical investigation into the wall collapse of wheat leaf cells caused by wheat streak mosaic virus infection. Physiol. Mol. Plant Pathol. 1995, 47, 379-389. [CrossRef]

44. Zellnig, G.; Pockl, M.H.; Mostl, S.; Zechmann, B. Two and three dimensional characterization of Zucchini Yellow Mosaic Virus induced structural alterations in Cucurbita pepo L. plants. J. Struct. Biol. 2014, 186, 245-252. [CrossRef]

45. Sochor, J.; Babula, P.; Adam, V.; Krska, B.; Kizek, R. Sharka: The past, the present and the future. Viruses 2012, 4, $2853-2901$. [CrossRef]

46. El-Deeb, S.H.; IsHak, J. Histological and cytological changes due to the infection with Sweetpotato feathery mottle virus (SPFMV). J. Plant Dis. Prot. 2004, 111, 247-256.

47. Sajjaanantakul, T.; van Buren, J.P.; Downing, D.L. Effect of methyl ester content on heat degradation of chelator-soluble carrot pectin. Food Sci. 1989, 54, 1272-1277. [CrossRef]

48. Sams, C.E. Preharvest factors affecting postharvest texture. Postharvest Biol. Technol. 1999, 15, 249-254. [CrossRef]

49. Lin, W.C.; Jolliffe, P.A. Light intensity and spectral quality affect fruit growth and shelf life of greenhouse-grown long English cucumber. J. Am. Soc. Hortic. Sci. 1996, 121, 1168-1173. [CrossRef]

50. Toivonen, P.M.; Hodges, D.M. Abiotic stress in harvested fruits and vegetables. In Abiotic Stress in Plants-Mechanisms and Adaptations; InTech: Rijeka, Croatia, 2011; pp. 39-58.

51. Kubo, Y.; Xue, Y.; Nakatsuka, A.; Mathooko, F.M.; Inaba, A.; Nakamura, R. Expression of a water stress-induced polygalacturonase gene in harvested cucumber fruit. J. Jpn. Soc. Hortic. Sci. 2000, 69, 273-279. [CrossRef]

52. Shibairo, S.I.; Upadhyaya, M.K.; Toivonen, P.M. Changes in water potential, osmotic potential, and tissue electrolyte leakage during mass loss in carrots stored under different conditions. Sci. Hortic. 2002, 95, 13-21. [CrossRef]

53. Morawicki, R.O.; Schmalko, M.E. Prediction of out-of-container pasteurization of pickled cucumbers using the finite-difference method. J. Food Eng. 2011, 107, 289-295. [CrossRef]

54. Al-Shahwan, I.M.; Abdalla, O.A.; Al-Saleh, M.A. Response of greenhouse-grown cucumber cultivars to an isolate of zucchini yellow mosaic virus (ZYMV). APS 1995, 79. [CrossRef]

55. Fletcher, J.T.; George, A.J.; Green, D.E. Cucumber green mottle mosaic virus, its effect on yield and its control in the Lea Valley, England. Plant Pathol. 1969, 18, 16-22. [CrossRef]

56. Prendeville, H.R.; Tenhumberg, B.; Pilson, D. Effects of virus on plant fecundity and population dynamics. New Phytol. 2014, 202, 1346-1356. [CrossRef]

57. Fraile, A.; García-Arenal, F. Environment and evolution modulate plant virus pathogenesis. Curr. Opin. Virol. 2016, 17, 50-56. [CrossRef] [PubMed] 